\title{
Charisma, Volatility and Violence
}

\section{Assessing the Role of Crises of Charismatic Authority in Precipitating Incidents of Millenarian Violence}

\section{Introduction}

In this article I intend to develop some of the points I have made elsewhere regarding the role of what may be termed 'crises of charismatic authority' in producing volatility or even violence within marginal apocalyptic religious groups (see Walliss 2004, 2005b and forthcoming). The last quarter of the twentieth century witnessed several incidents where such groups engaged in violent actions against themselves, others in the outside world, or typically both. On November 18, 1978, in Jonestown, Guyana, over nine hundred members of Peoples Temple, a Californian religious movement led by Jim Jones, died in an act of collective 'revolutionary suicide'; almost a decade-and-a-half later, seventy-four members of the Branch Davidians, a Seventh-Day Adventist splinter group, met a fiery end at the conclusion of a 51-day standoff with US authorities at their home at Mount Carmel, Waco, Texas; between October 1994 and March 1997, around seventy-four members of the Order of the Solar Temple died in a series of ritualised murder-suicides in Switzerland, Quebec and France; in March 1995, members of Aum Shinrikyō, a Japanese group already implicated in at least twenty-three other murders, launched an abortive attack on the Tokyo underground using the nerve gas sarin, an attack that could easily have resulted in thousands of fatalities; two years later, thirty-nine members of a group calling itself Heaven's Gate committed collective suicide in the apparent belief that the world was about to be 'spaded under', and that they could escape the destruction via a space ship hiding behind the then-passing Hale-Bopp comet; finally, in Uganda, in the spring of 2000, around 780 members of the Movement for the Restoration of the Ten Commandments of God (hereafter MRTCG) died in a series of murder-suicides, the details and exact reasons for which are still unclear.

In my analyses of these incidents I have argued against the 'cultural opposition' thesis, put forward most notably by John Hall and his associ- 
ates and David Bromley, that these incidents were precipitated largely, if not exclusively, by external opposition; that the combination of apostates, hostile media coverage and the intervention of the state/law enforcement agencies led these groups to commit violence (Hall and Schuyler 1998, Hall et al. 2000, Bromley 2002). Although I accept that this model provides a good description of the broad scheme of events leading up to the confrontation at Mt Carmel (see Tabor and Gallagher 1995; Walliss 2004: Chapter 3), my own assessment of the other incidents has led me to argue that external opposition is neither necessary nor sufficient in itself to precipitate violence/volatility and that, consequently, the focus of attention should be shifted away from an exclusive concern with external factors. In particular, I have argued that Catherine Wessinger's notion of 'fragile millennial groups' provides a much more useful model for understanding the 'dramatic denouements', as Bromley terms them, of Peoples Temple, the Order of the Solar Temple, and Aum Shinrikyō (Wessinger 1997, 2000a and 2000b).

Like all religious groups, Wessinger (2000a: 15) argues, millennial/millenarian groups possess an 'ultimate concern' - 'a concern which is more important than anything else for the person [or group] involved'. When this concern - or 'millennial goal' - is threatened in some way, she continues, a group may become volatile and in some cases may either try to preserve or fulfil their goal through acts of violence. So, for example, they may strike out at their real or perceived opponents in the outside world, or, through an act of collective suicide, effectively remove themselves from the situation. A 'fragile millennial group', according to Wessinger engages in violence because their ultimate concern/millennial goal is threatened in some way by a combination of external opposition and internal pressures; the former typically exacerbating the effects of the latter. This, to my mind, provides a more accurate description of these three incidents than that provided by the 'cultural opposition' thesis.

However, in my discussion of the Heaven's Gate collective suicide and the mass homicide/suicide of the MRTCG, I have argued that the 'fragility model' needs modifying to account for these incidents. Although it is impossible to rule out the possibility that external opposition may have played some role in precipitating these incidents, the balance of evidence would suggest that they were the result of internal issues or pressures alone. So, for example, the MRTCGs dramatic denouement would appear to have been precipitated by 'a crisis of charismatic authority' coupled with defections and demands from former members that donations be refunded to them stemming from a series of failed prophecies throughout 
the 1990s. Although patchy, the balance of evidence would seem to suggest that being either unwilling or unable to refund donations to their dissatisfied followers, the MRTCG leadership set about liquidating any opponents before engineering their own and their follower's deaths, or, according to some accounts, fleeing Uganda with the money (Atuhaire 2003, Mayer 2001a, Ugandan Human Rights Commission [hereafter UHRC] 2002, Walliss 2005a).

This notion of 'crises of charismatic authority' has in many ways become a central, recurring theme in my analysis of these incidents. While accepting that such crises were typically not sufficient in themselves to have precipitated each of the dramatic denouements I have examined, I have come to the conclusion that they did play a major role in each. Indeed, I would argue that such crises played a much more significant role than that played by external opposition in almost all of the cases I examined (the case of the Branch Davidians being perhaps the exception that proves the rule). In this chapter, I intend to discuss what I mean by crises of charismatic authority (an important task in itself due to the diverse understandings of 'charisma' found within the literature) and to present a comparative analysis of some of the ways in which these crises can occur.

\section{Charisma}

All sociological discussions of charisma invariably have as their starting point the seminal work of Max Weber, who discussed 'charismatic authority', along with 'traditional' and 'legal rational' authority, in his work on ideal-type forms of legitimation/domination (see Weber 1947, 1978 and 1991). Although there is debate over some of the ambiguities in his treatment of the phenomenon, (particularly whether, or to what extent, Weber considered charisma to be a characteristic of individuals), the consensus among commentators is that for Weber charismatic authority was inherently relational. From this perspective, charisma is not something that individuals possess, but, rather, is the outcome of an interactive social process whereby a specific individual's claim to charisma is recognised and accepted by others, typically potential followers (Wilson 1975, Wallis 1993, Dawson 1998 and 2002). As Bryan Wilson notes,

Charisma denotes not the quality of the individual, but of a relationship between believers (or followers) and the man in whom they believed. His claim, or theirs on his behalf, was that he had authority because of his super- 
natural competences. Charisma is not a personality attribute, but a successful claim to power by virtue of supernatural ordination. (Wilson 1975: 7, emphasis added.)

One consequence of this, Weber and his successors have argued, is that charismatic authority must constantly be 'proven' or 'demonstrated': the prophet, for example, must perform miracles, the warlord must deliver great victories, the political leader must deliver political successes and so on (Weber 1947: 359 and 1991: 248-9). In this way, charismatic authority thus requires constant 'impression management' (Goffman 1974, Gardner and Avolio 1998) or 'legitimation work' (Dawson 2002), whereby the leader attempts to maintain their authority through a variety of charismatic displays of power or 'signs of the miraculous' (Wallis 1983: 8). When this does not occur - when such 'signs' or 'proofs' are lacking - their followers may come to believe that their master has been 'forsaken by the gods' or that 'his magical or heroic powers have deserted him' (Weber 1947: 360). In such cases, charismatic leaders may be said to have suffered a 'loss of charisma'. Thus, Weber cites the example of the monarchs in ancient China, noting how

... the charismatic quality of the monarch, which was transmitted unchanged by heredity was upheld so rigidly that any misfortune whatever, not only defeats in war, but droughts, floods, or astronomical phenomena which was considered unlucky, forced him to do public penance and might even force his abdication. If such things occurred, it was a sign that he did not possess the requisite charismatic virtue, he was thus not a legitimate 'Son of Heaven'. (Weber 1947: 360.)

'Crises of charismatic authority', then, are situations when charismatic leaders' 'legitimation work' / attempts at impression management break down and where consequently their claims of seemingly miraculous powers are called into question. As Dawson (2002: 98, 81, emphasis added) rightly points out, 'charismatic authority is not intrinsically dangerous'. Rather, 'the true danger stems ... from the mismanagement of certain endemic problems of charismatic authority that are rooted in the problematic legitimacy of charisma'. More specifically, he argues 'the potential for violence in new religious movements stems, in part, from failing to cope with the more or less perpetual legitimation crises experienced by charismatic leaders' (Dawson 2002: 85, emphasis added). Such crises may take innumerable forms, and, equally, there are innumerable ways in which they may be 
resolved without bringing about volatility (see, for example, the literature on failed prophecy - Dawson 1999, Stone 2000). However, within the cases that I shall examine, three broad types may be highlighted as having been especially significant in precipitating each group's violence: loss of reputation or real/perceived rebuffs; being exposed as having used trickery or deceit; and, finally, suffering from a loss of health. This is not to suggest of course that these crises were the sole factors. In most of the cases, while I would argue they played a significant role, these crises typically interacted with other factors, sometimes internal, sometimes external. Nor is it to suggest that crises such as these will automatically lead to volatility / violence in similar cases. Rather my aim is to show, firstly, how these crises were manifested in the particular cases and, secondly, to offer some thoughts about the role of such crises in precipitating incidents of volatility/violence within marginal apocalyptic religious groups.

\section{Types of Crises}

\section{Loss of Reputation / Real or Perceived Rebuffs}

One way in which a leader's claims to charismatic authority may be undermined is through a loss of reputation or through real or perceived rebuffs. In the early 1990s, for example, Luc Jouret, one of the leaders of the Solar Temple was arrested in Canada following an attempt to illegally buy a gun with a silencer. Although Jouret and the others involved received minor sentences (a fine of $\$ 1,000$ each and one year unsupervised probation), he would appear to have been personally devastated by the verdict. Prior to this incident, Jouret had for several decades been a popular lecturer on the international New Age circuit, lecturing on such topics as 'Love and Biology', 'Christ, the Sphinx and the New Man', and 'Old Age: The Doorway to Eternal Youth' (indeed, this was one of Solar Temple's chief recruiting techniques and sources of income). However, following his conviction Jouret's reputation was effectively ruined and he found more and more doors closed to him. Not only this but a number of Solar Temple members left the group, embarrassed by Jouret's actions (Mayer 1998).

The loss of his reputation would appear to have affected Jouret very strongly and arguably played a key role in precipitating the 1994 'transit'. As one member later recalled, following the incident 'his mind changed, he was a tired, tired, tired, disappointed, disillusioned person' (quoted in Hall et al. 2000: 135). Similarly, police wiretaps of Jouret also, according to Jean-François Mayer (1999: 182), show that he 'was in a depressed mood, 
constantly complaining about feeling tired and expressing eagerness to leave the world'. Not only this, but the Solar Temple's theodicy underwent a radical transformation. The notion of an 'ecological apocalypse' had always been a central theme in Jouret's lectures and in the Solar Temple's beliefs; Jouret claiming that the earth, as a living entity, had become sick as a consequence of pollution and human environmental mismanagement. However, like a number of new age authors, Jouret linked this pessimistic vision with a more optimistic one concerning the transition from the Age of Pisces to the Age of Aquarius. According to Mayer, the Solar Temple saw its mission as to gather an elect group (referred to in some Solar Temple documents as 'Templars of the New Age') who would survive the ecological apocalypse and inaugurate 'the Kingdom of Aquarius' (Mayer 2001b). In 1986, for example, the Order published two books entitled Suvivre à l'An 2000 (Survival Beyond the Year 2000), the second volume of which dealt exclusively with 'survivalist' themes such as how to survive in the aftermath of atomic, bacteriological and chemical warfare attacks (Mayer 2001b, Introvigne 2000). Similarly, from the mid-1980s the Solar Temple began to found 'survival farms' in Canada, based on the belief that the area around Toronto in particular would experience fewer upheavals during the prophesied ecological meltdown because it was situated on a broad granite plate with a strong magnetic field. However, following Jouret's conviction, the subsequent defection of members and international police investigation into its activities, the Solar Temple's theodicy began to evolve from one of survivalism to one which emphasised the Gnostic escape from the shackles of the physical world to the world of the spirit prior to the prophesied apocalypse. This, as Mayer (1999) notes, had always been an aspect of the Solar Temple's theodicy, however, in the period following Jouret's conviction it came to gain more and more ascendancy until it seemingly eclipsed the belief in survivalism and provided the theological rationale for the October 1994 'Transits'.

Similarly, in the case of Aum Shinrikyō, a chain of events that began with its failure to achieve the international growth in membership predicted by its leader Asahara Shōkō, and the rejection of its application under the Religious Corporations Law in April 1989 served to undermine the image that Asahara was attempting to create for Aum. In its initial formulation, Aum saw its mission in similar terms to the Solar Temple. Like Luc Jouret, Asahara began in the mid-1980s to speak publicly about what he believed to be the very real possibility of a cataclysmic event in the near future that would herald the end of the world. In 1987, for example, he gave a number of talks in which he discussed the possibility of a nuclear war 
breaking out around 1999, describing how growing political and economic tensions between Japan and the rest of the world would lead Japan to rearm, and ultimately lead to an inevitable nuclear war some time between 1999 and 2003. Indeed, he claimed that his spirit had left his body and travelled forward in time to 2006, where it had discovered the aftermath of nuclear holocaust (see Shōkō 1988: 87-94).

Nevertheless, despite this pessimistic view, Asahara's message was at its core more optimistic (Reader 2000b). According to Asahara, the mass destruction that he had prophesied was the result of the negative karmic repercussions of materialism and, as such, could be averted through positive spiritual action. For this to occur, however, he claimed that it was imperative for Aum to open at least one centre in every country and also train thirty thousand spiritually enlightened renunciates (shukkesha) by 1993. More broadly, Aum saw its mission - a mission that Asahara claimed to have had entrusted to him by Shiva - as the creation of the Buddhist paradise on earth, Shambhala, first in Japan and then extending throughout the world. To this end, beginning in 1988, Aum began to build self-sufficient communal 'Lotus Villages' where members could renounce their attachments to the outside world and devote themselves fully to their spiritual practice away from the negativity and temptations of the world (Reader 1997).

However, within a very brief period of time it became apparent that such plans were far too ambitious to be achieved. Although Aum had managed to persuade a number of individuals to renounce the world and become shukkesha, it had not attracted them in sufficient numbers to meet the targets for world salvation. Between 1986 and 1988, for example, the number of shukkesha increased from three to 113, while the number of lay members grew from 35 to around 4,000. Nevertheless, while such growth was indeed impressive it fell far short of the rate required to meet the pressing apocalyptic timetable. Indeed, by as late as 1990 Aum had recruited less than two per cent of the number of shukkesha required to avert the prophesied disaster, and also showed little sign of opening up the required number of centres worldwide (Reader 1997 and 2000b).

Shortly afterwards, in April 1989 Aum had its application for registration under the Japanese Religious Corporations Law rejected. Although such applications are on the whole usually fairly straightforward affairs, Aum's application was met with fierce opposition by both disgruntled exmembers and the families of shukkesha, who complained that not only had their children severed all contacts with them when they joined Aum, but that any attempts to make contact with them had been blocked by Aum. 
Aum was thus painted as an organisation that not only denied families access to its members but also sought to break families up. Consequently, its application was turned down. (Brackett 1996, Reader 2000a.) Although its application was accepted later that year, Aum then came under pressure from 'cultural opposition' in the form of the media and from a group of aggrieved former members and families of members, calling itself the 'Aum Victims' Society'.

Finally, perhaps most damningly, Aum's attempts to achieve political power during the 1990 elections ended in a debacle. In July 1989, Asahara announced that in order to further its salvational activities, Aum would form a political party, the Shinrito (Supreme Truth Party), to campaign in the following February's general election for the Lower House of the Japanese Diet. According to Asahara, such a move was necessary in order to both alert the Japanese public to the coming catastrophe, and advance Aum's Shambhala project. Asahara went on to predict that the Shinritō would secure victory in the elections and that he himself would come top of the ballot. However, this was not to be. Rather, Aum's whole election campaign quickly descended into what Daniel A. Metraux (2000: 43) refers to as 'one embarrassing joke - a public display of twisted idolatry and mind control that revolted the public'. Although Aum did indeed have some campaign themes (such as 'freedom, equality, and benevolence for every being, especially for every Japanese'), the majority of its campaigning took the form of Aum members gathering in front of subway stations wearing papier-mâché heads of Asahara and the Hindu deity Ganesh while singing the Shinritō campaign song:

Shōkō, Shōkō, Shōkō-Shōkō-Shōkō, Asahara Shōkō

Shōkō, Shōkō, Shōkō-Shōkō-Shōkō, Asahara Shōkō

Japan's Shōkō, the world's Shōkō, the earth's Shōkō, Shōkō, Shōkō

He rises now, shining brilliantly

Let's put ourselves in the hands of our youthful hero

To protect our Japan, we need his strength

Shōkō, Shōkō, Asahara Shōkō

(Quoted in Metraux 2000: 45.)

Perhaps not surprisingly, Aum's campaign was widely ridiculed in the press and all the Shinrito candidates lost heavily as, indeed, did Asahara himself who managed to field only 1,783 votes in a district where around 500,000 ballots were cast. Not only this, but the media became even more 
scathing of Aum, with 'AUM-bashing' becoming a veritable 'national pastime' and 'media obsession' (Young 1995: 232). In the aftermath of the elections and what he perceived to be the Japanese public's scornful rejection of his offer of salvation, Asahara announced that Aum would cease in its efforts to save the world, and would henceforth focus instead on saving its members alone. It would also, although Asahara did not state this publicly, begin its preparations to defend itself against its perceived enemies by secretly developing various biological and chemical weapons (Reader 2000a and 2000b).

\section{Exposure of Trickery or Fraud}

Another form of crisis occurs when a leader is exposed as having practiced trickery or fraud. Charismatic authority, after all rests on the ability to produce 'signs of the miraculous' for one's followers and, perhaps most importantly, convincing them that they are genuine and a sign of election. Consequently, if such signs are revealed to be deliberately faked, then the consequences for the leader's perceived charismatic authority can be potentially disastrous - particularly, where (s)he cannot offer a convincing justification or explanation for what has transpired.

Joseph Di Mambro, for example, the co-leader along with Jouret of the Solar Temple, claimed to be in contact with a number of occult 'ascended masters', a claim that was seemingly supported by the appearance of said masters along with various other forms of supernatural phenomena (such as, for example, the Holy Grail and Excalibur) at the Order's rituals. Thus, to give an example, during the 'rite of conception' at which the Di Mambro claimed his daughter, the 'cosmic child' Emmanuelle, was immaculately conceived, an eight-foot tall ascended master, Manatanus, appeared, and directed a laser-beam across the sanctuary with his sword, lighting up the throat of Di Mambro's mistress, Dominique Bellaton with a flash (Palmer 1996). Similarly, one Canadian member quoted by the journalist Joseph Harriss described how 'during rituals we would hear sounds from the star Sirius, followed by apparitions of chandeliers, swords and so on, leading up to the appearance of the [ascended] Masters' (quoted in Harriss 1997: no pagination). Such phenomena, while they were no doubt impressive and seemingly convincing to those who beheld them were, nevertheless, somewhat less than miraculous in their origin; being the result of a combination of lighting and sound effects, slides, home-made props, and possibly unwittingly ingested hallucinogens. According to Harriss, who was shown some of the props at Sureté du Quebec headquarters in Montreal, 
'King Arthur's Excalibur was a large, tinny broadsword crudely painted fluorescent green and red. In a dark room, black light made it appear suspended in midair, blood dripping from the tip.' (Harriss 1997: no pagination.) Similarly, the sword wielded by Manatanus (actually Di Mambro's wife, Jocelyne, in disguise) in the conception rite 'had a small nine-volt battery taped to its hilt. Electrical wires, masked with black tape, led to a tiny light at the tip' (Harriss 1997: no pagination). Bellaton, for her part, had a small flashlight in her mouth that made her throat appear like it was glowing (Palmer 1996).

In 1990, Di Mambro's twenty-nine-year-old son, Elie, discovered the truth behind the staged rituals, having his suspicions confirmed by the lighting engineer behind them, a member called Antonio Dutoit. Dutoit subsequently left the Order (he and his family were, however, to be murdered as 'traitors' shortly before the 'Transits'), while Elie began to speak openly about what he had discovered (Palmer 1996, Wessinger 2000a). Although some members explained away the fakery as 'an unfortunate but necessary way to keep weaker souls within the fold' (Introvigne 2000: 151), many others, already embarrassed by Jouret's arrest and conviction, defected and demanded that the money that they had invested in the Order be refunded to them. As one member wrote to Di Mambro late in 1993:

Rumours about embezzlement and various [forms] of skulduggery are propagated by influential ex-members. Many members... have left or are leaving. They feel their ideals have been betrayed ... It is even said that you have fallen because of money and women, and you're no longer credible. This is very serious for the Order's mission.

There are even more serious grumblings, and you know them. Here they are: everything we saw and heard in certain places has been a trick. I have known this for some time. Tony [Dutoit] has been talking about this for years already ... I have always refused to pay attention to these rumours, but the evidence is growing, and questions are being asked. This calls into question many things I've seen, and messages. I would be really upset if I had to conclude that I'd sincerely prostrated myself in front of an illusion!!! (Quoted in Mayer 1999: 179.)

Similarly, from Aum's inception, Asahara had claimed that not only did he possess various supernatural abilities (such as, for example, ESP, the ability to see the future, and the ability to levitate), but that such abilities - and ultimately, liberation from karma and human suffering - could 
also be attained by those who joined Aum and followed the ascetic regime espoused by him. To this end, Aum developed a hierarchical series of initiations, many of which involved the utilisation (at a price) of various tonics, amulets or devices designed, it was claimed, to bring the user closer to the level of spiritual perfection attained by Asahara. For a 'donation’ of $¥ 1,000,000$ a month, for example, Aum members could rent Perfect Salvation Initiation (PSI) headsets, designed to deliver six-volt shocks to the wearer's scalp so as to synchronise his/her brainwaves with Asahara's (Reader 1997). For $¥ 22,000$, they could drink 'Miracle Pond’, a 200 millilitre vial of Asahara's bath water so as to imbibe some of his spiritual power. Snippets of Asahara's hair and beard trimmings were also brewed in boiling water and then drunk (Kaplan and Marshall 1997). However, the most prized initiation was the so called ‘Blood Initiation’ (cost: $¥ 1,000,000$ ) where the initiate drank a vial of Asahara's blood, again in the belief that in doing so (s)he would be able to imbibe some of his purportedly unique DNA and thereby become a more effective spiritual practitioner. As one Aum text declared;

The initiation of Blood comes from a secret Tantric rite wherein the blood of the guru is taken into one's own body. The introduction of the guru's internal tissue implies the introduction of the guru's holy karma, and hastens progress in purifying one's own karma, thus elevating one's practice.

Several days after receiving the Initiation of the Blood I experienced bardō (the world between death and rebirth). I was transformed, and while sitting in the lotus position I fell into a pitch-black dome. Although people are usually frightened by the experience of bardō, because the Master's bardō experience was input into my Causal world through the Initiation of the Blood I was not frightened at all. My psychological composure has also greatly increased. (Quoted in Shimazono 2001: 42.)

In 1989, however, a lawyer representing the Aum Victims' Society, Sakamoto Tsutsumi, began investigating the Blood Initiation and found that all was not as it was claimed by Aum. Asahara had claimed that his blood had been tested by the medical laboratories at Kyoto University and found to contain a unique DNA structure, which, he claimed, could be passed on to those who drank it. Sakamoto, however, discovered that no such tests had ever taken place and threatened to go public with this and 
file a case against Aum for fraud. ${ }^{1}$ Knowing the threat that this could pose to both his own perceived charismatic authority, as well as the damage it could cause to Aum's finances, reputation and mission, Asahara issued orders that Sakamoto should be murdered to silence him. Consequently, in November 1989, six Aum members broke into Sakamoto's apartment, killing Sakamoto along with his wife and baby, before burying the bodies in separate prefectures so as to complicate any subsequent police inquiries (Brackett 1996, Reader 2000b).

Yet another (albeit relatively rare) way in which a leader may be potentially exposed as a fraud is through the phenomena of prophetic disconfirmation. As noted previously, the literature on failed prophecy shows that not only does prophecy never really 'fail' in the eyes of believers, but that even when it may appear to have done so, leaders and prophets invariably deploy a whole raft of techniques and strategies to convince their followers that this is not the case (see Dawson 1999 for a discussion). When, however, prophecy does fail and a leader is unable to provide their followers with a convincing interpretation for what has (not) transpired, their perceived charisma may be severely undermined.

Thus, as noted previously, in the case of the MRTCG it would appear that a string of failed prophecies played an instrumental role in precipitating the spring 2000 murder-suicides. The available evidence indicates that the MRTCG leadership had predicted the end of the world for the end of 1992, and then the end of 1995, before finally settling on 31 December 1999. When the final date came and passed without incident, dissent began to grow among members. The Movement's prophet, Credonia Mwerinde, however, told them that the Virgin Mary had reappeared to her and the other leaders of the Movement, informing them that the date for the end of the world had been put back to 17 March 2000. Although this raised the spirits of some, a number of members were not convinced by this and discontent began to grow. Many, for example, began to demand that their donations be refunded, a situation that clearly threatened the Movement's fi-

1 Interestingly, Asahara had been exposed and convicted as a fraudster prior to forming Aum. In June 1982 he was jailed for 20 days and fined \$2,000 for selling fake Chinese cures (such as, for example, 'Almighty Medicine' which was tangerine peel in an alcohol solution - Kaplan and Marshall 1997). This incident bankrupted his small herbal medicine business and would appear to have affected Asahara deeply. Following his conviction, according to D. W. Brackett (1996: 64), Asahara 'was too embarrassed to face his neighbours. For some time after the trial and bankruptcy, he and his wife lived a hermit-like existence, only venturing outside at night to buy food and other essentials.' 
nancial viability and continued existence (Atuhaire 2003). Likewise, others became openly disloyal and began to question the authority of Mwerinde and the other leaders. One member, for example, later recalled how on one occasion:

one of the followers wrote a 96-page exercise book full of complaints and passed it under Credonia's office door. Later Credonia told other followers that someone had written an exercise book full of 'satanic things' which she had burnt. (UHRC 2002: 6.1.)

In an attempt to placate any dissenters, 'Credonia promised that the Blessed Virgin Mary would refund the money from the sale of the members' properties'. She also 'asked her priests to record the names of those followers who were discontented' (UHRC 2002: 6.1). Those who submitted complaints were, according to witnesses, called to a meeting with the MRTCG leaders and never seen again. Any who asked where these individuals had gone were informed that they had been transferred to another of the MRTCG's properties or 'that the Virgin had taken them to Heaven' (Atuhaire 2003; Banura et al. 2000). Having thus 'weeded out' the dissenters, it would appear that the MRTCG leaders then began to plan for the collective suicide of the faithful that would transpire on March 17.

\section{Loss of Health}

Finally, a leader's perceived charismatic authority can be undermined through real or perceived ill health. All but one of the leaders of the groups were in real or perceived ill health prior to their group's respective denouements. ${ }^{2}$ Following Jim Jones's move to Jonestown, for example, his health deteriorated seriously as a consequence of heavy drug use. Jonestown residents heard him speaking over the loudspeaker in slurred tones, saw him staggering around the community, urinating on occasions in public view, and all who came into contact with him witnessed signs of mental confusion and frequent, erratic changes in his mood. Jones had also put on weight and claimed to be seriously ill with several maladies, although this belief was contradicted by the subsequent autopsy on his body

2 The sole exception to this state of affairs is Joseph Kibwetere, one of the leaders of the MRTCG, although there is some speculation that he may have been dying of AIDS. This was certainly the view expressed in several reports following the March 2000 conflagration (see, for example, UHRC 2002: 3.3). 
(Maaga 1998). One member, for example, recalled that when she moved to Jonestown in December of that year, Jones, who she had not seen for several months, was a physical wreck;

He had gained a great deal of weight, and he complained constantly of such a number of serious ailments that it was a wonder he was still on his feet at all. He claimed to have cancer, a heart condition, a fungus in his lungs, and a recurring fever of 105 degrees. He dosed himself with painkillers, tranquillisers, and amphetamines, which only added to the incoherence of his speech. (Quoted in Maaga 1998: 92.)

Similarly, Ian Reader notes how 'followers and former followers confirmed that [Asahara] frequently appeared to be ill in 1994 and that when he spoke his voice seemed to be husky'. Indeed, 'when he was arrested in May 1995 Asahara was, by all accounts, overweight and in poor condition, and at that time there were many rumours that he was dying of liver failure or some such ailment'. (Reader 2000b: 170-1).

Health concerns also appear to have played a crucial role in both the development of the Heaven's Gate theodicy and the group's decision to commit collective suicide. From its inception in the early 1970s in Houston, Texas, the group's leaders, Marshall Applewhite and Bonnie Lu Nettles (or Do and Ti as they were known within the group), had always claimed that those who joined them, and who were able to shed their worldly attachments, would be taken up via a spaceship to what they termed 'the Next Level'. However, over time the exact details of this 'technological rapture' changed. Initially, Ti and Do had claimed that those who joined them would board the spaceship to the Next Level in their physical bodies. However, following Ti's death from cancer in 1985, this idea was abandoned in favour of the view that the physical body was simply a 'container' or 'vehicle' for the soul which could be 'jettisoned' if necessary prior to entering the Next Level. (Lewis 2003.) Just as Ti had left her 'vehicle' in order to complete her 'evolution' to the Next Level, so too could her followers.

Indeed, going further, the group came to believe that rather than being human beings, they were in fact an 'Away Team' of members of the Next Level. Thousands of years ago, Do claimed, members of the Next Level 'planted' all the various life forms in various 'gardens' (planets). Some, but not all, of the 'plants' however, were prepared ('prepped') to make the transition from the human realm to the Next Level by being 'tagged' with Next Level souls. Representatives of the Next Level (or 'Reps') then peri- 
odically descend to the human level, incarnate among humans and seek out the souls that have been tagged in order to offer them instruction in the knowledge and behaviour necessary to evolve to the Next Level. This, Do claimed, had happened twice in recorded human history; first two thousand years ago when a Next Level soul had incarnated into the 'vehicle' of Jesus, and now when two such souls had incarnated into the 'vehicles' of Applewhite and Nettles.

For members of Heaven's Gate, the earth was thus a 'classroom' where they learned how to shed their attachment to 'the human kingdom' and 'graduate' back to the Next Level. During the early 1990s, however, they began to receive signals that this time was coming to an end. Primarily, Do's health began to deteriorate and he began to delegate more and more responsibilities to his students and, indeed, began to speak of assuming the role of 'professor emeritus'. He also became convinced that he was dying of cancer, a belief later shown to be unfounded by the autopsy conducted on his 'vehicle'. (Hall et al. 2000, Balch and Taylor 2002.) However, the possibility that Do, like Ti, might die prior to leading his students on their return to the Next Level, presented the very real possibility that they could be 'shut-off' from the Next Level and essentially remain 'trapped' on earth. As Wessinger observes, the group's theodicy 'did not provide for the establishment of a lineage of leaders to succeed him. Do had stressed to his disciples that he was the only means by which they could enter the Kingdom of Heaven.' (Wessinger 2000a: 244; see also Lewis 2003.) If he died, not only would the students be without their teacher, but they would also be without their only guide back to the Next Level. As one member stated in their 'Earth Exit Statement' under the title 'Why I Want To Leave at This Time':

I know my Older Member, Do, is going to his Older Member, Ti, at this time. Once He is gone, there is nothing left here on the face of the Earth for me, no reason to stay a moment longer. Furthermore, I know that my graft to Them would be jeopardized if I linger here once They have departed. I know my classmates/siblings feel the same as I do and will be choosing to go when Do goes. ('Glnody' 1997: no pagination.)

Where the maladies of the above leaders were to a great extent imagined, those endured by Joseph Di Mambro were, in contrast, very real. Whereas Asahara was rumoured to be dying of liver failure, Di Mambro was actually suffering from this ailment and, indeed, had to wear incontinence pads. Likewise, whereas Jones and Do believed themselves to be dying of cancer, 
Di Mambro had been diagnosed as such. He had also contracted diabetes and had begun to experience diabetic fits (Wessinger 2000a).

\section{Concluding Thoughts}

In a recent discussion of the factors that may produce volatility within marginal religious movements, Thomas Robbins has offered several hypotheses for the apparent relationship between charismatic leadership and volatility. In the first instance, Robbins argues, because such leaders typically operate in a vacuum without any of the restraints or supports available to either traditional or legal-rational leaders, they are freer to 'act on impulse'. Whereas the bureaucratic leader must ideally follow set rules, procedures and guidelines, and the traditional leader must at the very least pay lip-service to tradition or custom, the charismatic leader must, as noted previously, sustain their own leadership through their actions. Linked to this, Robbins notes how, from a psychodynamic perspective, volatility/violence within charismatically-led groups may stem from the narcissistic relationship that exists between leader and follower within such groups. From this perspective;

... charismatic leaders may incline towards violence because, as narcissists, they perceived their followers as extensions of themselves, which may make them more willing to sacrifice their followers in a climatic confrontation or suicidal drama. Yet the orientation of the devotees to a charismatic leader may also have an element of narcissism ... Followers may tend to project their motives and aspirations onto the charismatic leader. Consequently, they can misread the leader's intentions and the direction in which he is taking the group. Volatility may thus be encouraged by both narcissistic leaders' objectification of their followers and the projective quality of the latter's identification with their prophet. (Robbins 2002: 73.)

Finally, stemming from both the above points, charismatic leaders may lack friends or associates who can offer him/her honest feedback on their ideas or actions, and may instead 'come to depend for reinforcement and adulation from uncritical devotees'. In such cases, Robbins argues, not only may high-level defections 'traumatise the leader and enhance group volatility', but 'the grandiose leader may become more extreme, unbalanced, and paranoid over time' (Robbins 2002: 74). 
While there are arguably elements of truth in Robbins's account, one criticism that is often made of attempts to locate the causes of incidents such as those discussed above with charismatic leadership per se is that, just as there exist numerous groups that hold often violently apocalyptic beliefs but yet do not engage in violent activities, so do there exist innumerable 'charismatic leaders' who have as yet not displayed any propensity towards volatility or violence (Dawson 2002; Bromley 2002: 46-7). How, then, can we account for the fact that as Lorne L. Dawson (2002: 80) observes, 'the impact of charismatic leadership is one of the constants of these incidents'? In this article, I have sought to expand on the ideas of Max Weber and more recently, Dawson to explore the links between the precariousness of charismatic authority and volatility in marginal apocalyptic groups. In each of the cases I have examined, the crises of charismatic authority experienced by the respective leaders served to undermine both their own perceived legitimacy, and by extension the group's millennial goal. However, only in the cases of the MRTCG and the Heaven's Gate group would these crises appear to have been sufficient in themselves to have precipitated their respective denouements. Rather, in the cases of Peoples Temple, the Order of the Solar Temple and Aum Shinrikyō, the various crises combined with other pressures, typically real or perceived external opposition, to make each groups 'fragile', to use Wessinger's terminology.

In this way, while crises of charismatic authority would appear to play a major role in precipitating incidents of volatility or violence in marginal apocalyptic groups, such crises are rarely sufficient causes in themselves. Rather, the evidence would seem to suggest that they serve instead as catalysts to the internal crises that can, when coupled with real or perceived external opposition, make such groups 'fragile' and thereby more prone to volatility or violence. In the majority of cases, such crises will be successfully resolved and not cause any lasting damage to the group in question. Rebuffs from the world, for example, may be interpreted as signs that the outside world is truly corrupt and evil. Similarly, 'failed' prophecies may be reinterpreted as tests of loyalty / faith, events that have been delayed as a consequence of the actions/prayers of the Elect, or even as events that have occurred, albeit in a spiritual rather than literal sense. However, in a small number of cases, the crises will not be so successfully resolved (or, indeed, may be irresolvable) and the leader's perceived charismatic authority, and by extension the group's continued existence/millennial goal, may become fatally undermined. Where this is already under threat from real or perceived cultural opposition, the group in question may then become 
volatile. They may also, more seriously, follow in the deadly footsteps of Peoples Temple, the Solar Temple, and Aum Shinrikyō and, in an attempt to either defend, salvage of fulfil their millennial goal, unleash violence on themselves and/or their perceived enemies in the outside world.

\section{References}

\section{Atuhaire, Bernard}

2003 The Uganda Cult Tragedy: A Private Investigation. London: Janus Publishing Company.

Balch, Robert W., and David Taylor

2002 Making Sense of the Heaven's Gate Suicides. In: David G. Bromley, and J. Gordon Melton (eds), Cults, Religion \& Violence; pp. 209-28. Cambridge: Cambridge University Press.

Banura, Gerard, Chris Tuhirirwe, and Joseph Begumanya

2000 Kanungu Research Team's Report. In: S. Kabazzi-Kisirinya, Deusdedit R. K. Nkurunziza, and Gerard Banura (eds), The Kanungu Cult-Saga: Suicide, Murder or Salvation?; pp. 12-46. Uganda: Department of Religious Studies, Makerere University.

\section{Brackett, D. W.}

1996 Holy Terror: Armageddon in Tokyo. New York: Weatherhill.

\section{Bromley, David G.}

2002 Dramatic Denouements, In: David G. Bromley, and J. Gordon Melton (eds), Cults, Religion $\mathcal{E}$ Violence; pp. 11-41. Cambridge: Cambridge University Press.

\section{Dawson, Lorne L.}

1998 Comprehending Cults: The Sociology of New Religious Movements. Oxford: Oxford University Press.

1999 When Prophecy Fails and Faith Persists: A Theoretical Overview. Nova Religio 3 (1): 60-82.

2002 Crises of Charismatic Legitimacy and Violent Behaviour in New Religious Movements. In: David G. Bromley, and J. Gordon Melton (eds), Cults, Religion E Violence; pp. 80-101. Cambridge: Cambridge University Press.

Gardner, William L., and Bruce J. Avolio

1998 The Charismatic Relationship: A Dramaturgical Perspective. Academy of Management Review 23 (1): 32-58.

\section{'Glnody'}

1997 'Earth Exit Statement'. www.heavensgate.com/misc/ exitgln.htm (accessed 17 March 2006).

\section{Goffman, Erving}

1974 The Presentation of Self in Everyday Life. Harmondsworth: Penguin Books. 
Hall, John R., and Philip Schuyler

1998 Apostasy, Apocalypse, and Religious Violence: An Exploratory Comparison of Peoples Temple, the Branch Davidians, and the Solar Temple. In: David G. Bromley (ed.), The Politics of Religious Apostasy: The Role of Apostates in the Transformation of Religious Movements; pp. 141-69. Westport, Connecticut: Praeger.

Hall, John R., Philip Schuyler, and Sylvaine Trinh

2000 Apocalypse Observed: Religious Movements and Violence in North America, Europe, and Japan. London: Routledge.

Harriss, Joseph A.

1997 Mystery of a Killer Cult. Readers Digest (International Edition). December.

Introvigne, Massimo

2000 The Magic of Death: The Suicides of the Solar Temple. In: Catherine Wessinger (ed.), Millennialism, Persecution and Violence: Historical Cases; pp. 138-57. New York: Syracuse University Press.

Kaplan, David E., and Andrew Marshall

1997 The Cult at the End of the World: The Incredible Story of Aum. London: Arrow Books.

Lewis, James $\mathbf{R}$.

2003 Legitimating Suicide: Heaven's Gate and New Age Ideology. In: Christopher Partridge (ed.), UFO Religions; pp. 103-28. London: Routledge.

Maaga, Margaret $\mathbf{M}$.

1998 Hearing the Voices of Jonestown: Putting a Human Face on an American Tragedy. New York: Syracuse University Press.

Mayer, Jean-François

1998 'Apocalyptic Millennialism in the West: The Case of the Solar Temple', a presentation held on Friday, November 13, 1998 at the University of Virginia. http:/ / www.healthsystem.virginia.edu/internet/ciag/reports/ report_apoc_index.cfm (accessed 17 March 2006).

1999 "Our Terrestrial Journey is Coming to an End": The Last Voyage of the Solar Temple'. Nova Religio 2 (2): 172-96.

2001a Fieldnotes: The Movement for the Restoration of the Ten Commandments of God. Nova Religio 5 (1): 203-10.

2001b The Dangers of Enlightenment: Apocalyptic Hopes and Anxieties in the Order of the Solar Temple. In: Richard Caron, Joscelyn Godwin, Wouter J. Hanegraaf, and Jean-Louis Vieillard-Baron (eds), Esotérisme, gnoses et imaginaire symbolique: Mélanges offerts à Antoine Faivre; pp. 437-51. Leuven: Peeters.

Metraux, Daniel A.

2000 Aum Shinrikyo's Impact on Japanese Society. New York: The Edwin Mellen Press.

Palmer, Susan J.

1996 Purity and Danger in the Solar Temple. Journal of Contemporary Religion 11 (3): 303-18. 


\section{Reader, Ian}

1997 A Poisonous Cocktail? Aum Shinrikyō's Path to Violence. Copenhagen: NIAS Publications.

2000a Imagined Persecution: Aum Shinrikyō, Millennialism, and the Legitimation of Violence'. In: Catherine Wessinger (ed.), Millennialism, Persecution and Violence: Historical Cases; pp. 158-82. New York: Syracuse University Press.

2000b Religious Violence in Contemporary Japan: The Case of Aum Shinrikyō. Surrey: Curzon.

\section{Robbins, Thomas}

2002 Sources of Volatility in Religious Movements. In: David G. Bromley, and J. Gordon Melton (eds), Cults, Religion and Violence; pp. 57-79. Cambridge: Cambridge University Press.

\section{Shimazono, Susumu}

2001 The Evolution of Aum Shinrikyō as a Religious Movement. In: Robert J. Kisala, and Mark R. Mullins (eds), Religion and Social Crisis in Japan: Understanding Japanese Society through the Aum Affair; pp. 19-52. Basingstoke: Palgrave.

Shōkō, Asahara

1988 Supreme Initiation: An Empirical Spiritual Science for the Supreme Truth. New York: AUM USA Co., Ltd.

Stone, Jon (ed.)

2000 Expecting Armageddon: Essential Readings in Failed Prophecy. London: Routledge.

Tabor, James D., and Eugene V. Gallagher

1995 Why Waco? Cults and the Battle for Religious Freedom in America. Berkeley: University of California Press.

\section{Ugandan Human Rights Commission [UHRC]}

2002 The Kanungu Massacre: The Movement for the Restoration of the Ten Commandments of God Indicted. Uganda: Uganda Human Rights Commission.

Wallis, Roy

1983 Sex, Violence, and Religion. Update: A Quarterly Journal of Religious Movements 7 (4): 3-11.

1993 Charisma and Explanation. In: Eileen Barker, James A. Beckford, and Karel Dobbelaere (eds), Secularisation, Rationalism, and Sectarianism: Essays in Honour of Bryan R. Wilson; pp. 167-79. Oxford: Clarendon Press.

\section{Walliss, John}

2004 Apocalyptic Trajectories: Millenarianism and Violence in the Contemporary World. Bern: Peter Lang.

2005a Making Sense of the Movement for the Restoration of the Ten Commandments of God. Nova Religio 9 (1): 49-67.

2005b Millenarianism and Violence: Rethinking the Role of Cultural Opposition. Paper presented to the CESNUR Conference, Palermo, Sicily, $4^{\text {th }}$ June 2005.

(Forthcoming) Crises of Charismatic Authority and Millenarian Violence: The Case 
of the Order of the Solar Temple. In: James R. Lewis (ed.), The Order of the Solar Temple. Aldershot: Ashgate.

\section{Weber, Max}

1947 The Theory of Social and Economic Organisation. Trans. A. M. Henderson and Talcott Parsons. London: Collier-Macmillan Ltd.

1978 Economy and Society: An Outline of Interpretive Sociology. Berkeley: University of California Press.

1991 The Sociology of Charismatic Authority. In Hans H. Gerth, and C. Wright Mills (eds), From Max Weber: Essays in Sociology; pp. 245-64. London: Routledge.

\section{Wessinger, Catherine}

1997 Millennialism With and Without the Mayhem. In: Thomas Robbins, and Susan J. Palmer (eds), Millennium, Messiahs and Mayhem: Contemporary Apocalyptic Movements; pp. 47-59. London: Routledge.

2000a How the Millennium Comes Violently: From Jonestown to Heaven's Gate. London: Seven Bridges Press.

2000b Introduction: The Interacting Dynamics of Millennial Beliefs, Persecution and Violence. In: Catherine Wessinger (ed.), Millennialism, Persecution and Violence: Historical Cases; pp. 3-39. New York: Syracuse University Press.

\section{Wilson, Bryan}

1975 The Noble Savages: The Primitive Origins of Charisma. London: University of California Press.

\section{Young, Richard F.}

1995 Lethal Achievements: Fragments of a Response to the Aum Shinrikyō Affair. Japanese Religions 20 (2): 230-45. 